\title{
PERAN INDONESIA DALAM RANTAI NILAI GLOBAL PRODUK ELEKTRONIK
}

\author{
Rizki Putri Nurdiati ${ }^{1}$, Rina Oktaviani ${ }^{2}$, Sahara $^{2}$ \\ ${ }^{1}$ Mahasiswa Program Pascasarjana Magister Manajemen dan Bisnis, IPB \\ ${ }^{2}$ Staf Pengajar FEM IPB
}

Artikel diterima Januari 2015

Artikel disetujui untuk dipublikasikan Juli 2015

\begin{abstract}
Globalization has transformed the structure of industry into global integration of socalled global value chains (GVCs). Some literatures suggest that electronic industry is known as a successful industry in establishing global value chain. Electronic industry is one of leading cluster in driving economic growth in Indonesia. This study aimed to analyze the role of Indonesia in electronic global value chain according to its share towards global electronic industry, linkages, and value added distribution. An input output analysis by using the Asian International Input Output Table 2005 was employed to analyze the share of each country in electronic global value chain, inter-sector linkages, value added, also output and income multiplier. The result showed that Indonesia had low participation in electronic global value chain. Indonesia's output share was the lowest among all countries which resulted in low valueadded acquisition. Indonesia played the role as the input user from the various sectors. It is suggested that Indonesia electronic manufacture sector should be integrated with the input supplier sectors. Electronic computing equipment sector can be the main priority in enhancing Indonesia electronic manufacture sector since it has the biggest effect to economic growth.
\end{abstract}

Keywords: electronic, global value chain, Indonesia, input output analysis

\section{PENDAHULUAN}

Istilah rantai nilai mengacu pada serangkaian kegiatan yang diperlukan untuk menghadirkan suatu produk (atau jasa) dimulai dari tahap konseptual, dilanjutkan dengan beberapa tahap produksi, hingga pengiriman ke konsumen akhir dan pemusnahan setelah penggunaannya (Kaplinsky 1999; Cattaneo et al. 2013). Definisi rantai nilai berdasarkan pendekatan yang luas melihat berbagai kegiatan kompleks yang dilakukan oleh berbagai pelaku (produsen utama, pengolah, pedagang, penyedia jasa) untuk membawa bahan baku melalui suatu rantai hingga menjadi produk akhir yang dijual. Rantai nilai ini dimulai dari suatu sistem produksi bahan baku yang akan terus terkait dengan kegiatan usaha lainnya dalam perdagangan, perakitan, pengolahan, dan lain-lain. Aktivitasaktivitas tersebut dapat dilakukan dalam satu perusahaan atau dapat pula dilakukan oleh beberapa perusahaan. Seiring dengan semakin berkembangnya industri, aktivitasaktivitas tersebut kemudian semakin tersebar ke beberapa negara sehingga rantai nilai tersebut menjadi global.

Rantai nilai global (global value chain) merupakan sebuah fenomena dimana setiap negara memainkan perannya masing-masing sebagai penyedia bahan baku, produk antara, dan barang jadi (DJKPI 2012). Ciri utama dari rantai nilai global adalah sistem produksi yang tersebar dan terbagi di beberapa lokasi di berbagai 
negara di seluruh dunia sehingga menghasilkan tingkat efisiensi tertinggi dan keuntungan yang lebih besar di setiap bagian sistem produksi. Penelitian sebelumnya mengenai rantai nilai global menunjukkan bahwa kemampuan dalam bergabung dalam suatu rantai nilai global menjadi hal penting bagi perkembangan negara, terutama bagi negara-negara berpenghasilan rendah (Gereffi dan Stark 2011).

Rantai nilai global dapat dilihat di berbagai industri di dunia, salah satunya adalah dalam industri elektronik. Industri elektronik merupakan salah satu industri terbesar dan juga paling cepat berkembang dalam ekonomi global (Sturgeon dan Kawakami 2010; Soejachmoen 2012). Cepatnya perkembangan dalam industri elektronik tersebut dipicu oleh adanya fragmentasi produk dan juga didukung oleh karakteristik industri elektronik sendiri (Soejachmoen 2012). Powers (2012) dalam penelitiannya mengemukakan bahwa proses produksi yang semakin terintegrasi secara global menyebabkan terjadinya perubahan dalam industri. Perubahan tersebut sangat terlihat dalam industri elektronik.

Perkembangan rantai nilai global dalam industri elektronik dimulai pada tahun 1970 dimana perusahaanperusahaan elektronik dari negara maju berpindah ke negara berkembang, seperti Malaysia, Singapura, Taiwan, dan Thailand (Chalmers 1991; ILO 2014), lalu pada awal tahun 1980-an mulai memasuki Tiongkok, Indonesia, Filipina, dan yang terbaru adalah India dan beberapa negara Eropa Timur, seperti Republik Ceko, Hungaria, Polandia, dan Rumania (Lüthje 2002; ILO 2014). Negara-negara Asia memiliki daya tarik yang cukup besar bagi pembentukan industri elektronik, baik subkontrak ataupun outsourcing, karena rendahnya upah tenaga kerja dan biaya-biaya lainnya, berlimpahnya bahan baku, dan kedekatan dengan pasar akhir utama (Van Liemt 2007, ILO 2014).

Industri elektronik dikenal sebagai industri yang paling berhasil dalam membangun rantai pasokan di seluruh dunia. Hal itu disebabkan oleh adanya perubahan dalam model pembagian kerja dalam proses produksi produk elektronik, dari yang semula vertical integrated atau produksi komponen hingga perakitan menjadi produk jadi dilakukan dalam satu pabrik, kemudian berubah menjadi horizontal integrated, dimana proses produksi sampai menghasilkan produk jadi dilakukan oleh beberapa perusahaan dan pabrik di negara berbeda. Fragmentasi horizontal yang terjadi dalam industri elektronik menjadi faktor penyebab banyaknya negara yang terlibat dalam rantai nilai suatu produk elektronik. Sejumlah negara, seperti Amerika Serikat, Jepang, Korea, Tiongkok, termasuk juga Indonesia ikut terlibat dalam proses produksi berbagai produk elektronik.

Dengan berpartisipasi dalam rantai nilai global, negara-negara yang terkait diharapkan memperoleh berbagai dampak positif, terutama dalam peningkatan daya saing produk, ekspansi produksi, dan akses ke pasar global yang lebih baik. Rantai nilai global juga diharapkan mampu mendorong peningkatan perekonomian sehubungan dengan nilai tambah yang diperoleh melalui rantai nilai tersebut. Kemampuan dalam bergabung dalam suatu rantai nilai global menjadi hal penting bagi perkembangan negara, terutama bagi negara-negara berpenghasilan rendah (Gereffi dan Stark 2011).

Beberapa penelitian menunjukkan permasalahan yang terjadi 
dalam rantai nilai global salah satunya adalah distribusi keuntungan yang tidak merata. Pengalaman negara-negara yang berpartisipasi dalam rantai nilai global menunjukkan bahwa keterkaitan dengan rantai nilai global tidak otomatis menghasilkan keuntungan bagi negaranya (Banga 2014). Xing dan Detert (2010) dalam penelitiannya mengungkapkan dalam produksi iPhone, dari harga 500 US dollar (harga jual produk tahun 2009), Amerika menerima 331 US dollar, Jepang, Jerman, dan beberapa negara industri utama lain memperoleh 162 US dollar, sedangkan Tiongkok yang merupakan produsen dan eksportir terbesar iPhone hanya menerima 7 US dollar. Keuntungan berupa nilai tambah tertinggi tetap diperoleh perusahaan pemilik merk.

Di Indonesia, industri elektronik dan komponen elektronika merupakan salah satu klaster unggulan pendorong pertumbuhan ekonomi (Kadin 2010). Selain berkontribusi dalam pembentukan produk domestik bruto, industri ini juga berperan dalam penciptaan devisa melalui ekspor. Elektronik merupakan salah satu dari sepuluh komoditas utama ekspor Indonesia, selain tekstil, karet, sawit, produk hasil hutan, produk otomotif, dan beberapa produk unggulan lain. Ekspor produk-produk elektronik cenderung meningkat dari tahun ke tahun dengan rata-rata peningkatan sebesar $3 \%$ per tahun selama tahun 2009-2013 (Kementerian Perdagangan 2014). Negara tujuan ekspor produk elektronik Indonesia meliputi wilayah ASEAN, Uni Eropa, Amerika Serikat, Korea Selatan, Jepang, Tiongkok, dan beberapa wilayah lain, dimana ASEAN merupakan pangsa pasar ekspor produk elektronik terbesar bagi Indonesia, dengan negara importir utamanya yaitu Singapura, Malaysia, Filipina, Thailand, dan Vietnam (Kementerian Perdagangan 2014).

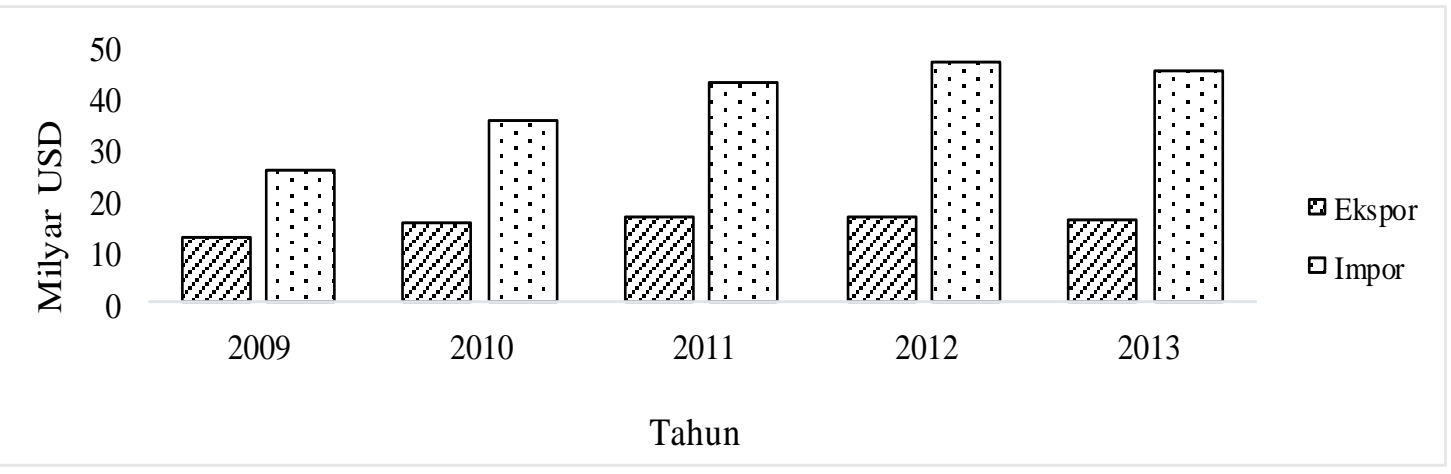

Sumber: WITS (2015), diolah

Gambar 1 Ekspor impor produk elektronik Indonesia tahun 2009-2013

Meskipun Indonesia memiliki pangsa pasar dunia yang relatif meningkat, tetapi industri elektronik Indonesia masih kurang kompetitif apabila dibandingkan dengan negara ASEAN lain, seperti Malaysia, Singapura, Thailand, dan Filipina (Setyawan 2011). Hal tersebut disebabkan oleh perkembangan industri yang belum optimal yang ditunjukkan oleh masih tingginya angka impor produk elektronik (Gambar 1). Ketergantungan tinggi pada bahan baku dan bahan modal impor menjadi alasan terjadinya hal tersebut (Ismail 2015). Pasar elektronik nasional masih dikuasai oleh produk-produk impor akibat daya saing produk nasional yang 
lebih rendah dibandingkan dengan produk impor (Lubis dan Asmara 2012). Produsen elektronik dalam negeri cenderung hanya melakukan proses perakitan di Indonesia, dimana bahan baku dan bahan modal bukan berasal dari dalam negeri, melainkan produk impor.

Berdasarkan latar belakang yang telah dikemukakan sebelumnya, terlihat bahwa industri elektronik telah memberikan kontribusi penting bagi ekonomi Indonesia. Industri elektronik menjadi komoditi ekspor unggulan Indonesia dan merupakan salah satu kontributor terbesar dalam ekspor manufaktur Indonesia. Indonesia juga memiliki peran penting dalam rantai nilai global produk elektronik karena menjadi kunci bagi jaringan manufaktur beberapa merk elektronik terkemuka (Kadarusman dan Nadvi 2013). Permasalahannya, partisipasi Indonesia dalam rantai nilai global produk elektronik juga belum tentu menghasilkan keuntungan besar karena pasar elektronik Indonesia juga masih dipenuhi oleh produk-produk impor yang menyebabkan angka impor produk elektronik Indonesia juga tinggi. Soejachmoen (2012) bahkan mengatakan bahwa Indonesia seperti 'menghilang' dari industri elektronik global karena peran Indonesia semakin menurun dari tahun ke tahun apabila dilihat dari share ekspor industri elektronik Indonesia, baik terhadap ekspor dunia, ekspor manufaktur Indonesia, maupun terhadap produk domestik bruto (PDB).

Terkait dengan permasalahan yang telah dikemukakan sebelumnya, maka tujuan dari penelitian ini adalah: 1) Menganalisis kontribusi industri elektronik Indonesia terhadap industri elektronik global, 2) Menganalisis keterkaitan industri elektronik Indonesia dengan negara lain, 3) Menganalisis distribusi nilai tambah dalam rantai nilai global produk elektronik, dan 4) Merumuskan implikasi manajerial dalam peningkatan peran Indonesia dalam rantai nilai global produk elektronik.

\section{METODE PENELITIAN}

\section{Jenis dan Sumber Data}

Penelitian ini menggunakan data sekunder berupa tabel Asian International Input Output (AIO) tahun 2005 yang tersedia secara online dalam website IDE-JETRO (www.ide.go.jp/ English/Data/Io/index.html). Tabel Asian International Input-Output (AIO) merupakan gabungan tabel transaksi perdagangan antara beberapa negara yang dikompilasi dan dirilis oleh Institute of Developing Economies Japan External Trade Organization (IDE-JETRO) dengan frekuensi setiap lima tahun. Tabel ini digunakan untuk melakukan analisa struktur industri dan keterkaitan hubungan perdagangan antar perekonomian di wilayah Asia Pasifik. Tabel AIO menggambarkan aliran barang dari satu negara ke negara lainnya yang berupa intermediate dan final demand sepuluh negara, meliputi Indonesia, Malaysia, Filipina, Singapura, Thailand, Tiongkok, Taiwan, Jepang, Korea Selatan, dan AS. Tabel AIO juga menyediakan informasi transaksi perdagangan dari dan ke negara lainnya, yaitu Hong Kong, Uni Eropa, dan Rest of The World (ROW) serta beberapa data perdagangan lainnya (IDE JETRO, 2014b). Sampai saat ini, tabel AIO telah dikompilasi untuk tahun 1985, 1990, 2000, dan yang terbaru adalah tabel AIO tahun 2005 yang dirilis pada bulan Maret 2014.

Tabel Asian International Input Output (AIO) 2005 merupakan tabel transaksi perdagangan antar negara yang terdiri atas 76 klasifikasi sektor. 
Untuk mempermudah dalam proses analisis, maka dilakukan agregasi menjadi sebelas sektor, dengan ketentuan sebagai berikut:

1. Sektor manufaktur elektronik, yang terdiri dari peralatan elektronik komputasi, semikonduktor dan integrated circuits, dan produk elektronik lain, dibagi menjadi tiga sektor.

2. Sektor-sektor elektronik lain yang menjadi produk elektronik konsumsi dikelompokkan menjadi satu sektor, yaitu sektor peralatan listrik lain.

3. Sektor lain yang tidak terkait atau tidak erat kaitannya dengan sektor manufaktur elektronik dikelompokkan sesuai dengan klasifikasi sektor sebagai berikut: pertanian, peternakan, kehutanan, dan perikanan, pertambangan dan penggalian, manufaktur, listrik, gas, dan air, konstruksi, perdagangan dan transportasi, dan jasa-jasa.

Industri elektronik yang dikaji dalam penelitian ini meliputi empat kategori, yaitu manufaktur peralatan listrik lain, peralatan elektronik komputasi, semikonduktor dan integrated circuits, dan produk elektronik lain. Penjelasan masingmasing kategori adalah sebagai berikut (BPS 2006):

1. Peralatan listrik lain (other electrical equipment)

Kategori ini mencakup:

1. Peralatan listrik berat, mencakup industri motor listrik, generator, dan transformator, industri peralatan pengontrol dan pendistribusian listrik, dan industri peralatan listrik yang tidak diklasifikasikan di tempat lain.

2. Perangkat televisi, radio, dan komunikasi, mencakup industri tabung dan katup elektronik serta komponen elektronik lainnya, industri alat transmisi komunikasi, dan industri radio, televisi, alatalat rekaman suara dan gambar, dan sejenisnya.

3. Peralatan listrik rumah tangga, mencakup usaha pembuatan peralatan rumah tangga yang tidak diklasifikasikan di tempat lain seperti pembuatan kompor, alat pemanas, dan alat pemanas ruangan dengan atau tanpa menggunakan arus listrik. Termasuk juga pembuatan selimut listrik, penghisap debu, pengkilat lantai, tempat sampah listrik, peralatan untuk mengolah dan mempersiapkan makanan, peralatan perawatan rambut, dan peralatan listrik lainnya.

4. Lampu, baterai, kabel, dan lainnya, mencakup industri kabel listrik dan telepon, industri akumulator listrik dan batu baterai, dan industri bola lampu pijar dan lampu penerangan.

2. Peralatan elektronik komputasi (electronic computing equipment)

Kategori ini mencakup usaha pembuatan mesin-mesin kantor, akuntansi, dan mesin komputasi secata manual, elektrik, dan elektronik termasuk pembuatan komponen atau suku cadang dan pemeliharaan/perbaikannya seperti: mesin hitung, mesin tik, mesin stensil, mesin peruncing pensil, berbagai mesin komputer, cash register, dan sejenisnya. Termasuk juga dalam kategori ini usaha pembuatan mesin fotokopi, mesin electronic sheet, mesin lightdruk dengan sistem optik atau contact type, termasuk perlengkapan dari mesin-mesin tersebut.

3. Semikonduktor dan integrated circuits (semiconductor and integrated circuits)

Kategori ini mencakup usaha pembuatan processor dan 
controllers, baik yang dilengkapi ataupun tidak dilengkapi dengan memory, converter, logic circuits, amplifier, clock and timing circuits, atau sirkuit lain, RAM (Random Access Memory), baik statis ataupun dinamis, dan amplifier

4. Produk elektronik lain (electronic and other electronic products)

Kategori ini mencakup:

1. Industri peralatan kedokteran dan perlengkapan orthopaedic, mencakup pembuatan peralatan untuk operasi, perawatan kedokteran gigi, peralatan sinar $\mathrm{X}$, perlengkapan orthopaedic dan prosthetic gigi palsu, dan peralatan tubuh palsu

2. Industri peralatan dan perlengkapan untuk pengukuran, pemeriksaan, pengujian, navigasi, dan maksud lain, mencakup usaha pembuatan alat pengukuran, pemeriksa, dan pengujian manual, pembuatan alat-alat laboratorium, dan alatalat pengukur dan pemeriksa elektronik

3. Industri peralatan pengujian dalam proses industri, mencakup pembuatan berbagai peralatan pengukuran dan pengujian dari barang-barang yang sedang diproses

4. Industri instrumen optik dan peralatan fotografi, mencakup usaha pembuatan macam-macam kacamata, teropong, kamera fotografi dan kamera sinematografi

5. Industri jam lonceng, dan sejenisnya, mencakup usaha pembuatan macam-macam jam dan bagian-bagiannya

\section{Analisis Input Output}

Dalam penelitian ini, analisis input output digunakan untuk menganalisis kontribusi, keterkaitan, dan distribusi nilai tambah dalam rantai nilai global produk elektronik. Analisis ini merupakan pendekatan yang tepat untuk mengkaji mengenai jaringan produksi, fragmentasi produksi internasional, rantai nilai global, dan sebagainya (Gou et al. 2009; Koopman et al. 2010; Meng et al. 2012). Pendekatan ini menggunakan tabel yang mampu memberikan gambaran menyeluruh tentang perekonomian suatu negara dalam aspek teknologi yang digunakan dalam proses produksi, penggunaan output yang dihasilkan dalam negeri, dan pendapatan dari produksi yang tercermin dari nilai tambah yang dihasilkan (Chung 2014).

Dalam bentuk persamaan, tabel input output disajikan sebagai berikut:

$$
\begin{gathered}
x_{11}+x_{12}+\ldots+x_{1 n}+F_{1}=X_{1} \\
x_{21}+x_{22}+\ldots+x_{2 n}+F_{2}=X_{2} \\
\vdots \\
\vdots \\
x_{n 1}+x_{n 2}+\ldots+x_{n n}+F_{n}=X_{n}
\end{gathered}
$$

Secara umum persamaan tersebut dapat dirumuskan kembali menjadi:

$\sum_{j=1}^{i} x_{i j}+F_{i}=X_{i} ; i=1,2,3, \ldots, n$

Dimana:

$x_{i j}$ : Banyaknya output sektor i yang digunakan sebagai input oleh sektor $\mathrm{j}$

$F_{i}$ : Permintaan akhir terhadap sektor i

$X_{i}$ : Total output sektor i

$n$ : Jumlah sektor

Apabila diketahui matriks koefisien teknis memiliki persamaan berikut:

$a_{i j}=\frac{x_{i j}}{X_{j}}$

maka substitusi persamaan (2) ke dalam persamaan (1) akan menghasilkan persamaan sebagai berikut:

$a_{11} X_{1}+a_{12} X_{2}+\ldots+a_{1 n} X_{n}+F_{1}=X_{1}$

$a_{21} X_{1}+a_{22} X_{2}+\ldots+a_{2 n} X_{n}+F_{2}=X_{2}$

$a_{n 1} X_{1}+a_{n 2} X_{2}+\ldots+a_{n n} X_{n}+F_{n}=\stackrel{\vdots}{X_{n}}$

Dalam bentuk matriks, persamaan tersebut dapat ditulis sebagai berikut: 
$\left[\begin{array}{cccc}a_{11} & a_{12} & \ldots & a_{1 n} \\ a_{21} & a_{22} & \ldots & a_{2 n} \\ \vdots & \vdots & \vdots \\ a_{n 1} & a_{n 2} & a_{n n}\end{array}\right]\left|\begin{array}{c}X_{1} \\ X_{2} \\ \vdots \\ X_{n}\end{array}\right|+\left|\begin{array}{c}F_{1} \\ F_{2} \\ \vdots \\ F_{n}\end{array}\right|=\left|\begin{array}{c}X_{1} \\ X_{2} \\ \vdots \\ X_{n}\end{array}\right|$

Jika ditulis dalam bentuk persamaan menjadi:

$A X+F=X$ atau $(I-A) X=F$ atau $X=(I-A)^{-1} F$

Dimana:

I : Matriks identitas

$F \quad:$ Permintaan akhir

X : Jumlah output

$(I-A) \quad$ : Matriks Leontief terbuka

$(I-A)^{-1}:$ Matriks kebalikan Leontief

1. Analisis Kontribusi

Analisis mengenai besarnya output yang dihasilkan oleh sektor manufaktur elektronik masingmasing negara, baik dalam bentuk input antara maupun permintaan akhir bertujuan untuk mengetahui seberapa besar peranan output masing-masing negara dalam pembentukan output keseluruhan dalam sektor manufaktur elektronik, serta peranan permintaan akhir dan input antara dalam pembentukan output sektor manufaktur elektronik di masing-masing negara.

a. Analisis Kontribusi Output

Analisis ini digunakan untuk melihat seberapa besar peranan dari output sektor manufaktur elektronik di masing-masing negara dalam membentuk output sektor manufaktur elektronik secara keseluruhan. Analisis kontribusi output dirumuskan sebagai berikut:

Output share negara ke- $\mathrm{i}=\frac{X_{i}}{\sum X_{i}}$

Dimana:

$$
\begin{aligned}
X_{i}: & \text { Nilai output sektor } \\
& \text { manufaktur elektronik } \\
& \text { negara i (ribu USD) }
\end{aligned}
$$

$\sum X_{i}$ : Nilai total output sektor manufaktur elektronik dari seluruh negara (ribu USD)

b. Analisis Kontribusi Permintaan Akhir

Analisis ini digunakan untuk melihat seberapa besar kontribusi permintaan akhir sektor manufaktur elektronik terhadap pembentukan nilai output sektor manufaktur elektronik di suatu negara. Analisis bagian permintaan akhir dirumuskan sebagai berikut:

Final demand share negara ke- $\mathrm{i}=$

Dimana:

$$
\frac{F_{i}}{X_{i}}
$$

$F_{i}$ : Nilai permintaan akhir sektor manufaktur elektronik negara i (ribu USD)

$X_{i} \quad$ : Nilai output sektor manufaktur elektronik negara i (ribu USD)

c. Analisis Bagian Input Antara

Analisis ini digunakan untuk melihat seberapa besar peranan input antara (input yang dihasilkan oleh negara lain) dari sektor manufaktur elektronik terhadap pembentukan output sektor manufaktur elektronik di suatu negara. Analisis bagian input antara dirumuskan sebagai berikut:

Intermediate input share negara

Dimana:

$$
\text { ke- } \mathrm{i}=\frac{I A_{i}}{X_{i}}
$$

$I A_{i}$ : Nilai input antara sektor manufaktur elektronik negara i (ribu USD)

$X_{i} \quad$ : Nilai output sektor manufaktur elektronik negara i (ribu USD) 
2. Analisis Keterkaitan

Analisis keterkaitan digunakan untuk mengidentifikasi para pelaku (negara) yang terkait dalam rantai nilai global. Analisis keterkaitan merupakan suatu analisis yang digunakan untuk mengetahui tingkat atau derajat keterkaitan suatu industri di suatu negara terhadap industri lain, baik di negara sendiri maupun di negara lain. Apabila suatu industri di suatu negara mendapat input dari industri lain maka dapat dikatakan adanya keterkaitan ke belakang (backward linkages), sedangkan keterkaitan ke depan (forward linkages) terjadi ketika industri tersebut menyumbang outputnya untuk menjadi input industri di negara sendiri maupun negara lain.

a. Keterkaitan ke Belakang (Backward Linkages)

Backward Linkages (BL) merupakan koefisien yang digunakan untuk melihat seberapa besar input yang diperoleh dari negara lain yang digunakan untuk menghasilkan output di dalam negeri. Suatu negara dikatakan memiliki keterkaitan ke belakang yang tinggi apabila indeks BL mempunyai nilai lebih besar dari satu (BL > 1). Dalam penelitian ini terdapat dua jenis keterkaitan ke belakang yang diteliti, yaitu keterkaitan ke belakang langsung dan keterkaitan ke belakang total (langsung dan tidak langsung).

Keterkaitan ke belakang langsung (direct backward linkage) merupakan efek langsung yang terjadi pada peningkatan penggunaan input produksi negara i akibat peningkatan permintaan akhir di negara i. Keterkaitan ke belakang langsung dapat dinotasikan sebagai berikut (Nazara 2005):

$$
B(d)_{j}=\sum_{i=1}^{n} a_{i j} ; a_{i j}=\frac{x_{i j}}{X_{j}}
$$

Dimana:

$B(d)_{j}$ : Indeks keterkaitan ke belakang total (keterkaitan ke belakang langsung dan tidak langsung) sektor manufaktur elektronik

$a_{i j} \quad$ : Matriks koefisien teknis sektor manufaktur elektronik

Keterkaitan ke belakang tersebut tidak hanya memiliki efek langsung, tetapi juga efek tidak langsung dari penambahan output, yang ditunjukkan oleh matriks kebalikan leontief. Keterkaitan ke belakang langsung dan tidak langsung dapat diketahui dengan menggunakan metode Rasmussen (Daryanto dan Hafizrianda 2010):

$B(d+i)_{j}=\sum_{i=1}^{n} g_{i j} ; g=(I-A)^{-1}$ Dimana:

$B(d+i)_{j}$ : Indeks keterkaitan ke belakang total (keterkaitan ke belakang langsung dan tidak langsung) sektor manufaktur elektronik

$g_{i j} \quad$ : Elemen matriks kebalikan Leontief model I-O terbuka untuk sektor manufaktur elektronik

b. Keterkaitan ke Depan (Forward Linkages)

Forward Linkages merupakan koefisien yang digunakan untuk melihat seberapa besar output yang dihasilkan dalam negeri yang menjadi input bagi kegiatan produksi di negara lain (ekspor produk antara). Suatu 
negara dikatakan memiliki keterkaitan ke depan yang tinggi apabila indeks FL lebih besar dari satu (FL > 1).

Keterkaitan ke depan langsung (direct forward linkage) menunjukkan distribusi tambahan output secara langsung kepada sektor produksi di masing-masing negara akibat adanya peningkatan output produksi di negara i. Keterkaitan ke depan langsung $\left(F(d)_{i}\right)$ dapat dinotasikan sebagai berikut (Nazara 2005):

$$
F(d)_{i}=\sum_{j=1}^{n} a_{i j}
$$

Efek langsung dan tidak langsung dari penambahan output tersebut ditunjukkan oleh indeks keterkaitan ke depan total, yang dapat diketahui dengan menggunakan metode Rasmussen (Daryanto dan Hafizrianda 2010):

$$
F(d+i)_{i}=\sum_{j=1}^{n} g_{i j}
$$

Dengan $F(d+i)_{i}$ merupakan indeks keterkaitan ke depan total, yaitu ukuran keterkaitan ke depan langsung dan tidak langsung.

3. Analisis Nilai Tambah

Analisis nilai tambah bertujuan untuk mengetahui pendapatan yang diperoleh masing-masing negara dari rantai nilai global produk elektronik. Pendekatan nilai tambah melalui tabel input output dipilih karena lebih tepat untuk mengukur pendapatan suatu negara dalam fenomena fragmentasi produksi global yang saat ini terjadi.

Nilai tambah bruto disebut juga sebagai balas jasa faktor produksi atau input primer. Nilai tambah bruto adalah balas jasa terhadap faktor produksi yang tercipta karena adanya kegiatan produksi. Nilai tambah merupakan jumlah total seluruh komponen nilai tambah, yang terdiri atas upah dan gaji (wages and salary), keuntungan usaha (operating surplus), penyusutan dari modal tetap (depreciation of fixed capital), dan pajak tak langsung netto (indirect taxes less subsidies). Nilai tambah dapat dirumuskan sebagai berikut:

$V A_{i}=L_{i}+S_{i}+D_{i}+T_{i}$

Dimana:

$V A_{i}$ : Nilai tambah (value added) sektor manufaktur elektronik negara i (ribu USD)

$L_{i} \quad$ : Nilai upah dan gaji sektor manufaktur elektronik negara i (ribu USD)

$S_{i}$ : Nilai surplus usaha sektor manufaktur elektronik negara i (ribu USD)

$D_{i}$ : Nilai penyusutan sektor manufaktur elektronik negara i (ribu USD)

$T_{i} \quad$ : Nilai pajak tak langsung netto sektor manufaktur elektronik negara i (ribu USD)

Definisi dari masing-masing komponen nilai tambah adalah sebagai berikut (BPS 2008):

a. Upah dan gaji mencakup seluruh balas jasa dalam bentuk uang kepada tenaga kerja yang ikut dalam kegiatan produksi.

b. Surplus usaha merupakan balas jasa atas kewiraswastaan dan pendapatan atas pemilik modal, yang mencakup keuntungan sebelum dikurangi pajak, bunga atas modal, sewa tanah, dan pendapatan atas hak kepemilikan lain.

c. Penyusutan merupakan biaya atas pemakaian barang modal tetap dalam kegiatan produksi. Nilai penyusutan dihitung dengan cara memperkirakan besarnya penurunan nilai dari barang modal tersebut yang disebabkan oleh 
pemakaiannya dalam kegiatan produksi.

d. Pajak tak langsung netto merupakan selisih antara pajak tak langsung dengan subsidi. Pajak tak langsung meliputi pajak impor, pajak ekspor, bea masuk, pajak pertambahan nilai, cukai, dan sebagainya.

4. Analisis Pengganda (Multiplier)

Analisis pengganda (multiplier) dilakukan untuk mengetahui peranan industri elektronik Indonesia dalam penciptaan output dan penggandaan pendapatan. Analisis multiplier menggambarkan bahwa terjadinya peningkatan aktivitas industri di suatu negara akan meningkatkan aktivitas industri di negara tersebut atau di negara lainnya sebesar nilai penggandanya. Analisis angka pengganda mencoba melihat apa yang terjadi pada variabel-variabel endogen tertentu apabila terjadi perubahan-perubahan variabel eksogen seperti permintaan akhir. Dalam penelitian ini, angka pengganda yang diukur meliputi angka pengganda output dan pendapatan.

a. Pengganda Output (Output Multiplier)

Matriks pengganda output merupakan suatu invers matriks yang digunakan sebagai suatu fungsi yang menghubungkan permintaan akhir dengan tingkat produksi. Angka pengganda output menunjukkan nilai total dari output yang dihasilkan oleh perekonomian untuk memenuhi adanya perubahan satu unit permintaan akhir di suatu sektor. Terdapat dua tipe dalam menghitung pengganda output, yaitu tipe I dan tipe II. Tipe I digunakan untuk menganalisis perubahan output akibat perubahan permintaan akhir baik secara langsung maupun tidak langsung dalam perekonomian suatu negara, sedangkan dalam tipe II efek induksi konsumsi ditambahkan dalam menganalisis perubahan output akibat perubahan permintaan akhir.

Angka pengganda output tipe I dapat diketahui melalui rumus berikut (Daryanto dan Hafizrianda 2010):

Dimana:

$$
o_{j}=\sum_{i=1}^{n} g_{i j}
$$

$o_{j}:$ Angka pengganda output sektor manufaktur elektronik negara $\mathrm{j}$ tipe I

$g_{i j}$ : Elemen matriks kebalikan Leontief sektor manufaktur elektronik untuk model I-O terbuka, dimana $G=(I-A)^{-1}$

Angka pengganda output tipe II dapat diketahui melalui rumus berikut (Daryanto dan Hafizrianda 2010):

Dimana:

$$
\bar{o}_{J}=\sum_{i=1}^{n} \overline{g_{i j}}
$$

$\overline{O_{J}}:$ Angka pengganda output sektor manufaktur elektronik negara $\mathrm{j}$ tipe II

$\overline{g_{i j}}$ : Elemen matriks kebalikan Leontief sektor manufaktur elektronik untuk model I-O tertutup, dimana $G=(I-A)^{-1}$

b. Pengganda Pendapatan (Income Multiplier)

Komponen pendapatan merupakan salah satu unsur dari input primer (nilai tambah) melalui upah dan gaji. Serupa dengan pengganda output, pengganda pendapatan juga memiliki dua tipe, yaitu tipe I 
dan tipe II. Angka pengganda pendapatan tipe I dapat dirumuskan sebagai berikut (Daryanto dan Hafizrianda 2010):

Dimana:

$$
Y_{j}=\frac{\sum_{i=1}^{n} P_{i} \times g_{i j}}{P_{i}}
$$

$$
\begin{array}{rlr}
Y_{j}: & \text { Angka } & \text { pengganda } \\
& \text { pendapatan } & \text { sektor } \\
& \text { manufaktur } \\
& \text { negara j tipe I } \\
P_{i}: & \text { Koefisien input upah/gaji } \\
& \text { sektor manufaktur elektronik } \\
& \text { di negara i } \\
g_{i j}: & \text { Elemen matriks kebalikan } \\
& \text { Leontief sektor manufaktur } \\
& \text { elektronik untuk model I-O } \\
& \text { terbuka, } \\
& G=(I-A)^{-1}
\end{array}
$$

Koefisien input upah/gaji merupakan suatu bilangan yang menunjukkan besarnya jumlah upah/gaji yang diterima oleh pekerja yang diperlukan untuk menghasilkan satu unit output. Koefisien input upah/gaji diperoleh melalui rumus berikut:

Dimana:

$$
P_{i}=\frac{L_{i}}{X_{i}}
$$

$P_{i}$ : Koefisien input upah/gaji sektor manufaktur elektronik di negara i

$L_{i}$ : Nilai upah dan gaji sektor manufaktur elektronik di negara i (ribu USD)

$X_{i}$ : Nilai input total sektor manufaktur elektronik di negara i (ribu USD)

Angka pengganda pendapatan tipe II dapat dirumuskan sebagai berikut (Daryanto dan Hafizrianda 2010):

Dimana:

$$
\begin{array}{rlr}
\bar{Y}_{j}: & \begin{array}{l}
\text { Angka } \\
\text { pendapatan }
\end{array} & \begin{array}{r}
\text { pengganda } \\
\text { sektor }
\end{array} \\
& \text { manufaktur } \\
& \text { negara j tipe II } \\
P_{i}: & \text { Koefisien input upah/gaji } \\
& \text { sektor manufaktur elektronik } \\
& \text { di negara i } \\
\overline{g_{i j}}: & \text { Elemen matriks kebalikan } \\
& \text { Leontief sektor manufaktur } \\
& \text { elektronik untuk model I-O } \\
& \text { tertutup, } \\
& G=(I-A)^{-1}
\end{array}
$$

\section{HASIL DAN PEMBAHASAN}

\section{Peran Industri Elektronik Indonesia terhadap Industri Elektronik Global}

Peran industri elektronik Indonesia terhadap industri elektronik global dilihat melalui empat faktor, yaitu struktur permintaan antara dan permintaan akhir, konsumsi, ekspor dan impor, serta investasi. Berdasarkan hasil analisis, diperoleh hasil sebagai berikut (Tabel 1):

1. Industri elektronik Indonesia memiliki nilai permintaan akhir yang lebih tinggi dibandingkan permintaan antara. Nilai permintaan antara yang lebih besar dibandingkan permintaan akhir menunjukkan peran sektor tersebut dalam produksi barangbarang elektronik. Findlay (2015) mengatakan industri elektronik Indonesia memiliki peran dalam proses pabrikasi dan perakitan barang elektronik. Manufaktur peralatan listrik lain merupakan sektor yang memiliki permintaan paling tinggi dalam industri elektronik Indonesia, baik permintaan terhadap produk antara maupun produk akhir.

2. Lebih dari $60 \%$ permintaan akhir industri elektronik Indonesia merupakan permintaan untuk konsumsi rumah tangga. Sektor manufaktur peralatan listrik lain 
merupakan sektor yang memiliki nilai konsumsi rumah tangga tertinggi, yaitu sekitar 54\% dari total konsumsi rumah tangga produk elektronik Indonesia. Hal tersebut dapat disebabkan oleh tingginya konsumsi terhadap produk elektronik rumah tangga seperti mesin cuci, pendingin ruangan, peralatan dapur yang menggunakan listrik, ataupun perangkat audiovisual seperti televisi, radio, dan barang elektronik lainnya.

3. Dalam industri elektronik Indonesia, terdapat dua sektor yang mengalami defisit dalam neraca perdagangan, yaitu sektor peralatan elektronik komputasi dan semikonduktor dan integrated circuits. Sektor yang berkontribusi besar dalam neraca perdagangan industri elektronik Indonesia adalah sektor peralatan listrik lain.

4. Sektor peralatan listrik lain memiliki jumlah investasi tertinggi dalam industri elektronik Indonesia yaitu sekitar $48 \%$ dari total investasi industri elektronik Indonesia.

Tabel 1 Peran industri elektronik Indonesia dalam industri elektronik global tahun 2005

\begin{tabular}{|c|c|c|c|}
\hline \multirow[b]{2}{*}{ Faktor } & \multicolumn{2}{|c|}{ Industri Elektronik Indonesia } & \multirow{2}{*}{$\begin{array}{c}\text { Industri } \\
\text { Elektronik Global } \\
\text { (Ribu USD) } \\
\end{array}$} \\
\hline & $\begin{array}{c}\text { Nilai } \\
\text { (Ribu USD) }\end{array}$ & $\begin{array}{c}\text { Persen } \\
(\%)\end{array}$ & \\
\hline Permintaan antara & $13,183,014$ & 0.84 & $1,572,002,608$ \\
\hline Permintaan akhir & $11,602,749$ & 1.87 & $619,385,391$ \\
\hline Konsumsi rumah tangga & $7,247,483$ & 3.34 & $216,866,853$ \\
\hline Ekspor-Impor & 916,252 & 0.78 & $118,008,878$ \\
\hline Investasi & $4,355,266$ & 1.13 & $386,227,104$ \\
\hline
\end{tabular}

Sumber: IDE-JETRO (2014a), diolah

\section{Kontribusi Industri Elektronik Indonesia terhadap Industri Elektronik Global}

Kontribusi output industri elektronik Indonesia dalam industri elektronik global hanya sekitar $1.06 \%$ atau sebesar 21 milyar US dollar (Tabel 2). Dari total output yang dihasilkan, $53 \%$ merupakan output untuk permintaan akhir, lalu 39\% merupakan produksi input antara, dan sisanya merupakan produksi yang ditujukan untuk ekspor ke India, Hongkong, Uni Eropa, dan rest of the world.

Mengingat Indonesia memiliki potensi yang cukup baik dalam industri elektronik dengan adanya pasar yang besar dan ketersediaan tenaga kerja yang tinggi, maka kontribusi tersebut masih sangat rendah, baik di sisi hulu maupun di hilir. Rendahnya tingkat output tersebut menjadi permasalahan utama industri elektronik Indonesia. Hal tersebut sejalan dengan laporan Bank Dunia (Samadikun 1985), yang menyatakan bahwa permasalahan utama dalam industri elektronik Indonesia adalah rendahnya produksi output yang disebabkan karena tidak adanya program ekspor yang signifikan dan rendahnya daya beli konsumen. 
Tabel 2 Nilai kontribusi masing-masing negara dalam industri elektronik global

\begin{tabular}{lccc}
\hline \multirow{2}{*}{ Negara } & \multicolumn{3}{c}{ Kontribusi (\%) } \\
\cline { 2 - 4 } & Output & Permintaan Akhir & Input Antara \\
\hline Indonesia & 1.06 & 53.15 & 38.61 \\
Malaysia & 4.04 & 26.40 & 52.04 \\
Filipina & 1.76 & 18.51 & 60.27 \\
Singapura & 2.37 & 9.18 & 53.25 \\
Thailand & 2.16 & 28.31 & 53.30 \\
Tiongkok & 28.10 & 25.32 & 45.68 \\
Taiwan & 5.99 & 20.74 & 45.94 \\
Korea & 8.99 & 21.89 & 53.10 \\
Jepang & 22.17 & 29.45 & 57.84 \\
Amerika & 23.36 & 37.26 & 44.58 \\
\hline Sina
\end{tabular}

Sumber: IDE-JETRO (2014a), diolah

Output sektor peralatan listrik lain mendominasi output industri elektronik Indonesia dengan kontribusi lebih dari $60 \%$ atau nilai output sebesar 13 milyar US dollar (Gambar 2). Dari output tersebut, $46 \%$ merupakan output berupa produk jadi, $41 \%$ merupakan output berupa input antara, dan sisanya ditujukan untuk ekspor ke negara lain.
Sektor produk elektronik lain memiliki kontribusi terbesar kedua dengan persentase sekitar 22\%, kemudian sektor semikonduktor dan integrated circuits di posisi ketiga dengan kontribusi sekitar 15\%, dan sektor peralatan elektronik komputasi memiliki kontribusi output terendah dengan persentase sebesar $1 \%$.

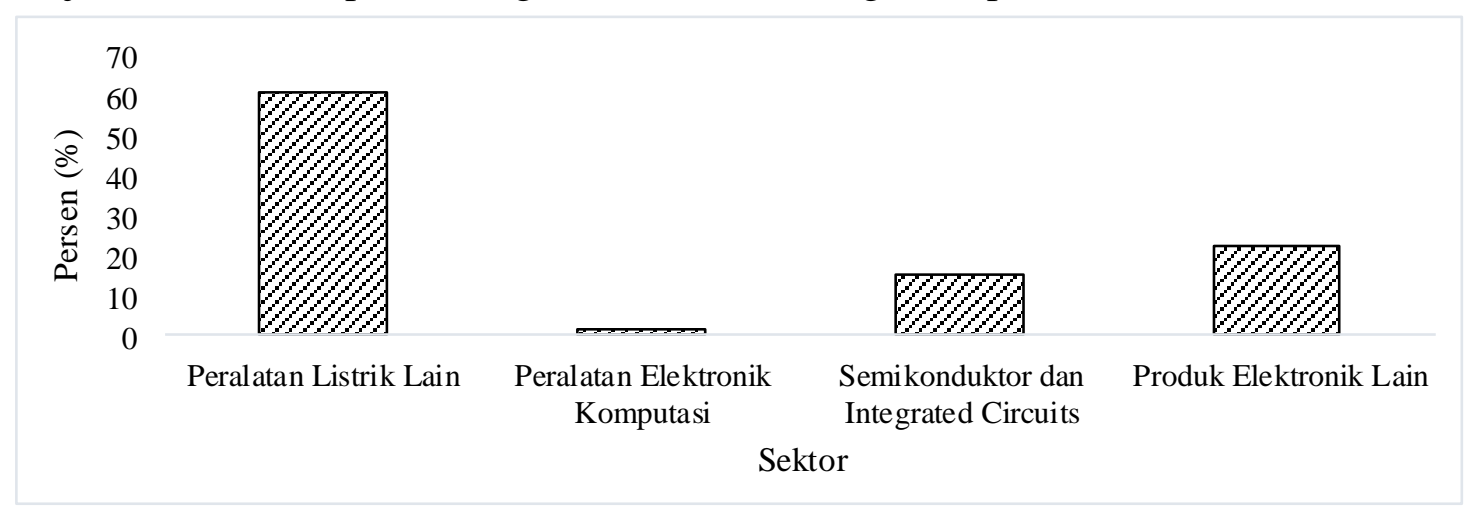

Sumber: IDE-JETRO, 2014a (diolah)

Gambar 2 Output industri elektronik Indonesia tahun 2005

\section{Keterkaitan Industri Elektronik Indonesia dengan Negara Lain}

Menurut Kuwamori dan Okamoto (2007), analisis keterkaitan antar industri dan antar negara dapat digunakan untuk melihat bagaimana struktur dari rantai nilai lintas negara. Berdasarkan hasil analisis keterkaitan ke depan dan ke belakang, diketahui bahwa keterkaitan ke belakang industri elektronik Indonesia lebih besar dibandingkan dengan keterkaitan ke depan. Hal tersebut sesuai dengan penelitian Hayashi (2005) yang menyatakan bahwa industri elektronik Indonesia merupakan industri yang lebih banyak memproduksi untuk konsumsi akhir dengan keterkaitan ke belakang yang tinggi. Berbagai kebijakan yang diterapkan oleh 
pemerintah, seperti pembebasan bea masuk untuk barang-barang input akan semakin meningkatkan efek keterkaitan ke belakang (Hayashi 2005). Tingginya angka keterkaitan ke belakang menunjukkan bahwa industri elektronik Indonesia memiliki kontribusi lebih besar sebagai pengguna input dari berbagai sektor, daripada sebagai penyedia input bagi berbagai sektor di negara lain maupun di Indonesia sendiri. Sektor manufaktur elektronik Indonesia memiliki peran yang cukup besar hanya pada sektor manufaktur elektronik di negaranya sendiri, belum mampu mendorong produksi sektor lain di Indonesia maupun di negara lain.

Industri elektronik Indonesia merupakan salah satu negara yang memiliki keterkaitan ke belakang, baik langsung maupun total yang tinggi. Sektor peralatan elektronik komputasi merupakan sektor yang memiliki angka keterkaitan paling tinggi dibandingkan tiga sektor lainnya (Gambar 3), dengan sebesar seribu US dollar. koefisien keterkaitan ke belakang langsung sebesar 0.81 dan koefisien keterkaitan ke belakang total sebesar 2.59. Koefisien keterkaitan ke belakang langsung menunjukkan bahwa apabila terjadi peningkatan permintaan akhir terhadap peralatan elektronik komputasi global sebesar seribu US dollar, maka sektor manufaktur peralatan elektronik komputasi Indonesia akan secara langsung meningkatkan permintaan terhadap inputnya sendiri maupun terhadap input dari sektor lain ataupun negara lain masing-masing sebesar 0.81 ribu US dollar. Sedangkan koefisien keterkaitan ke belakang total menunjukkan bahwa sektor peralatan elektronik komputasi Indonesia akan secara langsung dan tidak langsung meningkatkan permintaan terhadap inputnya sendiri maupun terhadap input dari berbagai sektor di negara lain masing-masing sebesar 2.59 ribu US dollar apabila terjadi peningkatan permintaan akhir elektronik global

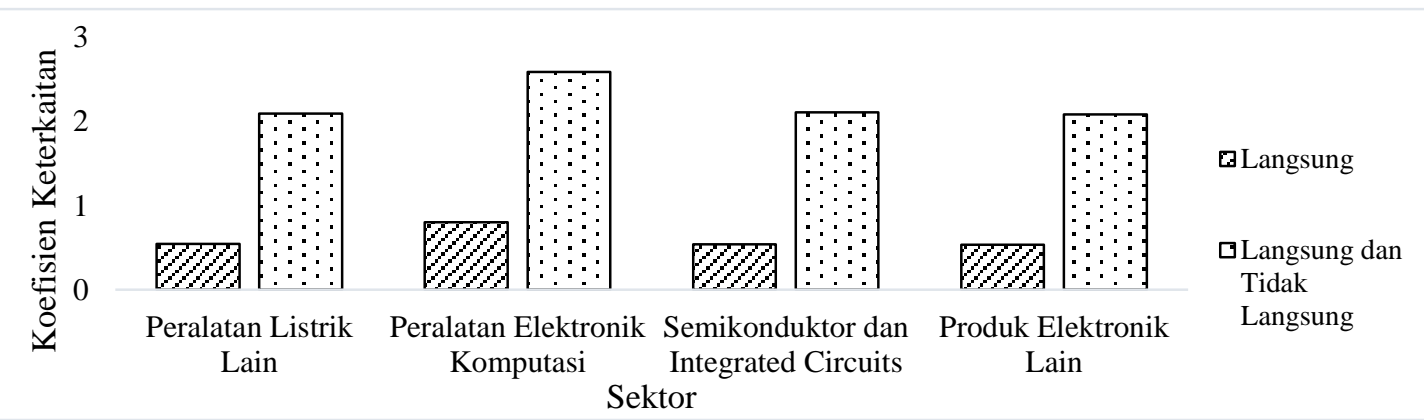

Sumber: IDE-JETRO, 2014a (diolah)

Gambar 3 Keterkaitan ke belakang industri elektronik Indonesia tahun 2005

Tingginya nilai keterkaitan ke belakang dalam sektor peralatan elektronik komputasi menunjukkan bahwa sektor ini lebih memerlukan pasokan input dari berbagai sektor di negara sendiri juga negara lain untuk meningkatkan outputnya dibandingkan ketiga sektor lainnya. Tiga sektor lainnya juga menunjukkan koefisien keterkaitan ke belakang yang cukup tinggi, meskipun koefisien tersebut lebih rendah apabila dibandingkan dengan rata-rata keterkaitan ke belakang. Hal tersebut menunjukkan bahwa tiga sektor tersebut juga merupakan pengguna input dari berbagai sektor lain, baik di negara sendiri maupun negara lain.

Selanjutnya, analisis keterkaitan ke depan (forward linkage) 
menunjukkan bahwa sektor peralatan listrik lain memiliki angka keterkaitan ke depan yang paling tinggi dengan koefisien keterkaitan ke depan langsung sebesar 0.48 dan koefisien keterkaitan total sebesar 1.63 (Gambar 4). Koefisien keterkaitan langsung ke depan menunjukkan bahwa apabila terjadi kenaikan permintaan akhir dari sektor peralatan listrik lain global sebesar seribu US dollar, maka output sektor manufaktur peralatan listrik lain Indonesia yang secara langsung dialokasikan ke berbagai sektor di negara lain, maupun ke Indonesia sendiri, akan mengalami peningkatan sebesar 0.48 ribu US dollar. Koefisien keterkaitan ke depan total menunjukkan apabila terdapat peningkatan permintaan akhir dari sektor peralatan listrik lain global sebesar seribu US dollar, maka akan meningkatkan output sektor peralatan listrik lain Indonesia sebesar 1.63 ribu US dollar yang dialokasikan baik secara langsung maupun tidak langsung kepada berbagai sektor di negara lain, maupun ke Indonesia sendiri.

Industri elektronik Indonesia memiliki angka keterkaitan ke depan yang rendah apabila dibandingkan dengan negara-negara lain. Hal tersebut disebabkan oleh mayoritas output yang dihasilkan industri elektronik Indonesia merupakan output untuk penggunaan dalam negeri. Industri elektronik Indonesia lebih banyak menjadi pemasok bagi sektor-sektor lain di dalam negeri, dengan sektor peralatan elektronik komputasi sebagai pengguna input utama.

2

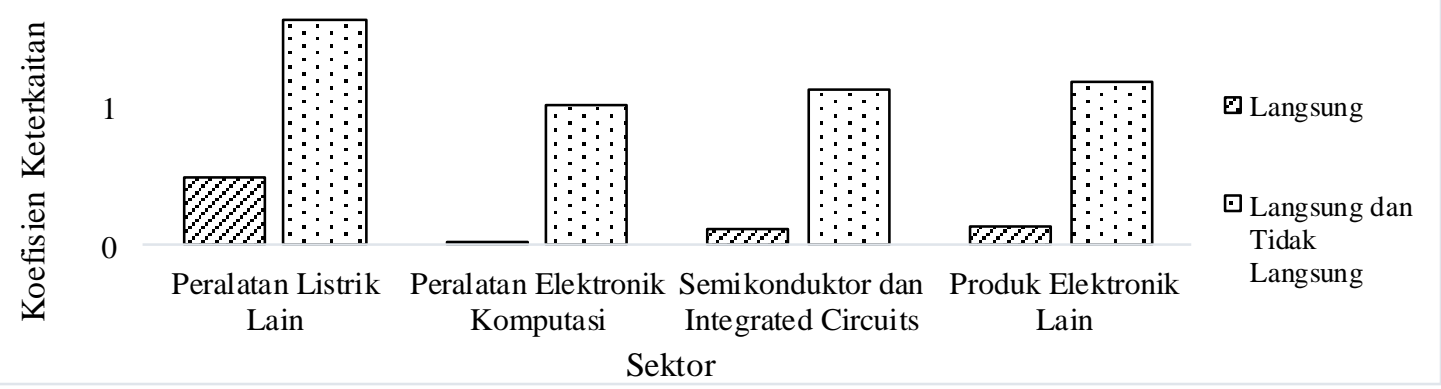

Sumber: IDE-JETRO, 2014a (diolah)

Gambar 4 Keterkaitan ke depan industri elektronik Indonesia tahun 2005

\section{DISTRIBUSI NILAI TAMBAH DALAM RANTAI NILAI GLOBAL PRODUK ELEKTRONIK}

\section{Nilai Tambah dalam Industri Elektronik Indonesia}

Nilai tambah bruto merupakan balas jasa terhadap faktor-faktor produksi yang terdiri empat komponen, yaitu upah dan gaji, surplus usaha, penyusutan, dan pajak tak langsung. Dengan melakukan analisis nilai tambah, maka dapat diketahui seberapa besar keuntungan yang diperoleh masing-masing negara dalam rantai nilai global produk elektronik.

Indonesia memperoleh nilai tambah terendah dengan persentase kurang dari $1 \%$ atau hanya sebesar 7,6 milyar US dollar. Sektor yang menghasilkan nilai tambah tertinggi bagi industri elektronik Indonesia yaitu sektor peralatan listrik lain yang menyumbang lebih dari $60 \%$ nilai tambah bagi industri elektronik Indonesia. Besarnya nilai tambah yang diperoleh masing-masing negara tergantung kepada seberapa banyak 
output yang diproduksi masing-masing negara.

Rendahnya nilai tambah yang diperoleh Indonesia menunjukkan bahwa Indonesia masih belum berhasil dalam memperoleh manfaat yang lebih besar dari jaringan produksi lintas negara. Rendahnya produksi output yang menjadi salah satu penyebab dari rendahnya perolehan nilai tambah ini mengindikasikan bahwa Indonesia belum berpartisipasi aktif dalam rantai nilai global. Beberapa tantangan yang dihadapi Indonesia untuk meningkatkan partisipasi dalam jaringan produksi global, di antaranya (Soejachmoen 2012):

a. Kualitas dan kuantitas infrastruktur

b. Kurang terbukanya lingkungan bisnis Indonesia terhadap investasi asing

c. Kualitas dan ketersediaan tenaga kerja terampil

Tabel 3 Struktur nilai tambah bruto sektor manufaktur elektronik global tahun 2005

\begin{tabular}{|c|c|c|c|c|c|c|}
\hline \multirow[b]{2}{*}{ Negara } & \multicolumn{6}{|c|}{ Nilai Tambah Bruto (Milyar USD) } \\
\hline & $\begin{array}{c}\text { Peralatan } \\
\text { Listrik } \\
\text { Lain }\end{array}$ & $\begin{array}{c}\text { Peralatan } \\
\text { Elektronik } \\
\text { Komputasi }\end{array}$ & $\begin{array}{c}\text { Semikonduktor } \\
\text { dan Integrated } \\
\text { Circuits }\end{array}$ & $\begin{array}{c}\text { Produk } \\
\text { Elektronik } \\
\text { Lain }\end{array}$ & Total & $\begin{array}{c}\text { Persen } \\
(\%)\end{array}$ \\
\hline Indonesia & 4,72 & 0,07 & 1,08 & 1,73 & 7,60 & 0,85 \\
\hline Malaysia & 4,50 & 4,99 & 3,20 & 0,91 & 13,61 & 1,52 \\
\hline Filipina & 1,97 & 1,41 & 4,00 & 0,73 & 8,10 & 0,90 \\
\hline Singapura & 0,59 & 3,14 & 5,49 & 1,36 & 10,58 & 1,18 \\
\hline Thailand & 3,37 & 2,87 & 0,85 & 1,01 & 8,10 & 0,90 \\
\hline Tiongkok & 63,01 & 20,32 & 14,90 & 3,08 & 101,31 & 11,28 \\
\hline Taiwan & 3,83 & 3,01 & 12,68 & 11,10 & 30,62 & 3,41 \\
\hline Korea & 18,40 & 2,07 & 12,59 & 11,87 & 44,92 & 5,00 \\
\hline Jepang & 61,36 & 10,17 & 16,33 & 44,65 & 132,51 & 14,76 \\
\hline Amerika & 416,69 & 26,24 & 35,97 & 61,60 & 540,50 & 60,20 \\
\hline Total & 578,44 & 74,28 & 107,08 & 138,05 & 897,85 & 100,00 \\
\hline
\end{tabular}

Sumber: IDE-JETRO, 2014a (diolah)

Surplus usaha memberikan kontribusi terbesar dalam penciptaan nilai tambah sektor manufaktur elektronik Indonesia (Gambar 5). Lebih dari separuh nilai tambah yang diperoleh industri elektronik Indonesia berupa surplus usaha, yang terdiri dari surplus usaha peralatan listrik lain sebesar 2,3 milyar US dollar, peralatan elektronik komputasi sebesar 39 juta US dollar, semikonduktor dan integrated circuits sebesar 611 juta US dollar, dan produk elektronik lain sebesar 981 juta
US dollar. Kontribusi terbesar kedua dalam pembentuk nilai tambah bruto adalah upah dan gaji dengan kontribusi sekitar $25 \%$ atau sebesar 1,9 milyar US dollar. Penyusutan menempati posisi ketiga dengan kontribusi sekitar 19\% atau sebesar 1,4 milyar US dollar. Pajak tak langsung memberikan kontribusi paling rendah dengan kontribusi sebesar 335 juta US dollar atau sekitar 4\% dari total nilai tambah bruto sektor manufaktur elektronik Indonesia. 


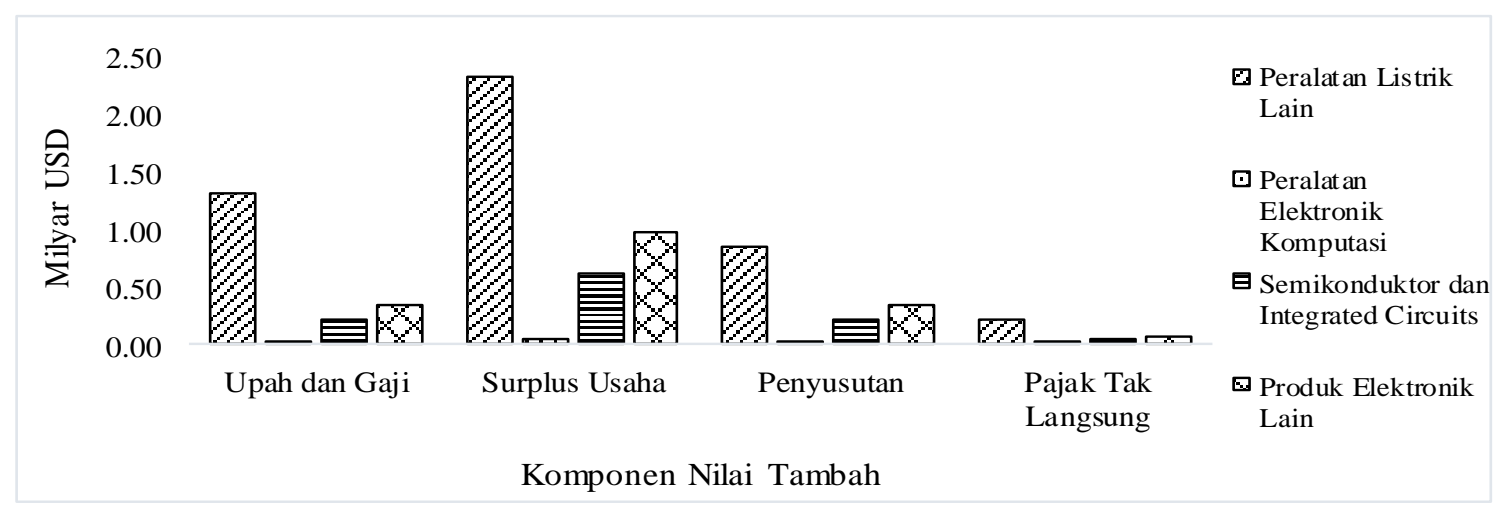

Sumber: IDE-JETRO, 2014a (diolah)

Gambar 5 Nilai tambah masing-masing komponen dalam industri elektronik Indonesia tahun 2005

\section{Angka Pengganda Industri Elektronik Indonesia}

Analisis angka pengganda bertujuan untuk melihat dampak perubahan dari peningkatan permintaan akhir sektor manufaktur elektronik di suatu negara terhadap pertumbuhan output dan pendapatan. Angka pengganda mencerminkan urutan prioritas investasi apabila ingin mendapatkan nilai dampak yang optimal, khususnya dampak positif untuk setiap jenis penggandanya (DEKIN 2012). Besar kecilnya angka pengganda tergantung pada luasnya hubungan ekonomi dan intensitas interaksi ekonomi dengan sektor lain, baik di negara sendiri maupun di negara lain (Sutrisna 2011). Dalam penelitian ini terdapat dua jenis analisis penganda yang dikaji, yaitu pengganda output (output multiplier) dan pengganda pendapatan (income multiplier).

Analisis pengganda output dan pendapatan masing-masing kemudian dibagi menjadi dua tipe, yaitu tipe I dan tipe II. Pengganda tipe I diperoleh dari pengolahan lebih lanjut dari matriks kebalikan Leontief terbuka, sedangkan pengganda tipe II diperoleh dari matriks kebalikan Leontief tertutup dengan memasukan komponen rumah tangga sebagai endogenous dari model. Pada pengganda output tipe I dan tipe II, dampak diukur untuk tiap satu satuan perubahan output, sedangkan pada pengganda pendapatan, dampak diukur untuk tiap satu satuan pendapatan.
a. Pengganda
Output
(Output
Multiplier)
Dalam industri elektronik Indonesia, sektor yang memiliki dampak pengganda output terbesar adalah sektor peralatan elektronik komputasi (Gambar 6). Sektor ini memiliki angka pengganda output tipe I sebesar 2.59 dan pengganda output tipe II sebesar 3,61. Nilai pengganda output tipe I menunjukkan bahwa adanya shock atau goncangan berupa peningkatan permintaan akhir pada sektor tersebut sebesar seribu US dollar maka akan meningkatkan output sektorsektor lain, baik di negara sendiri maupun negara lain, sebesar 2,59 ribu US dollar. Sedangkan pengganda output tipe II menunjukkan bahwa adanya peningkatan permintaan akhir beserta konsumsi rumah tangga pada sektor tersebut sebesar seribu US dollar, maka akan meningkatkan output sektor-sektor lain, baik di negara sendiri maupun di negara lain, sebesar 3,61 ribu US dollar.

Tingginya angka pengganda output pada sektor peralatan elektronik 
komputasi disebabkan oleh tingginya intensitas interaksi sektor ini terhadap sektor lain yang ditunjukkan oleh angka keterkaitan ke belakang. Berdasarkan pembahasan mengenai keterkaitan ke belakang industri elektronik Indonesia, diketahui bahwa input sektor peralatan elektronik komputasi mayoritas berasal dari sektor-sektor lain dalam negeri. Oleh karena itu, peningkatan permintaan akhir pada sektor peralatan elektronik komputasi akan mendorong peningkatan output sektor-sektor lain dalam negeri, yang berarti terjadinya peningkatan output perekonomian nasional. Tingginya angka pengganda output menunjukkan bahwa sektor ini dapat menjadi andalan bagi pengembangan industri elektronik Indonesia karena dampak pengganda output yang lebih besar dibandingkan dengan sektor lainnya.

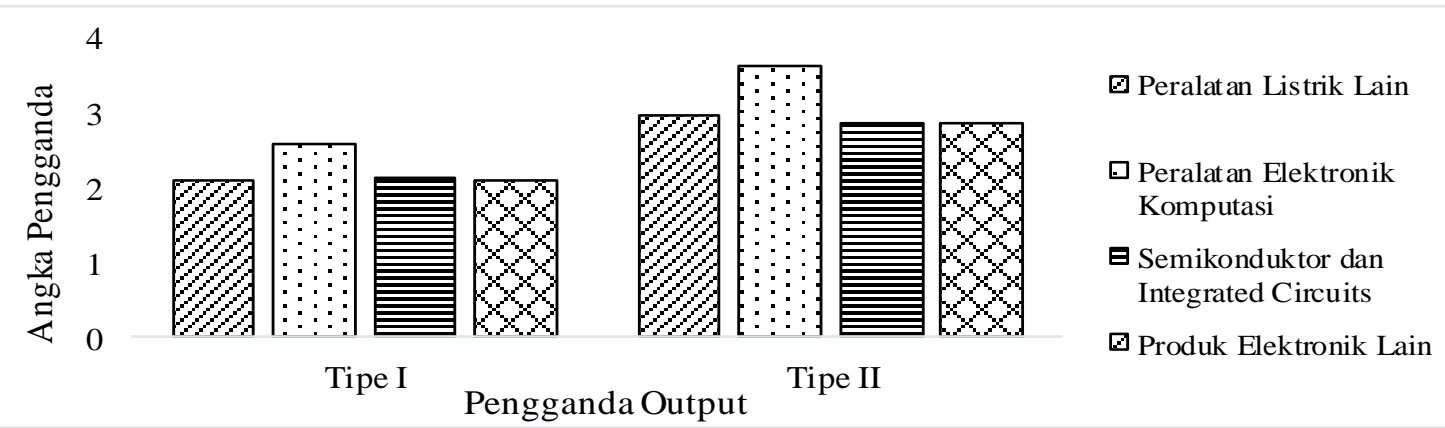

Sumber: IDE-JETRO, 2014a (diolah)

Gambar 6 Pengganda output tipe I dan tipe II industri elektronik Indonesia tahun 2005

\section{b. Pengganda Pendapatan (Income Multiplier)}

Sektor yang memiliki dampak pengganda pendapatan terbesar dalam industri elektronik Indonesia adalah sektor peralatan elektronik komputasi (Gambar 7). Sektor ini memiliki angka pengganda pendapatan tipe I sebesar 6,37 dan pengganda pendapatan tipe II sebesar 11,99. Nilai pengganda pendapatan tipe I menunjukkan bahwa setiap peningkatan permintaan akhir dari sektor manufaktur peralatan elektronik komputasi Indonesia sebesar seribu US dollar, maka akan meningkatkan pendapatan sektor-sektor lain, baik di negara sendiri maupun di negara lain sebesar 6,37 ribu US dollar. Sedangkan nilai pengganda tipe II menunjukkan bahwa adanya peningkatan permintaan akhir besera konsumsi rumah tangga pada sektor tersebut sebesar seribu US dollar, maka akan meningkatkan pendapatan masyarakat di sektor lain, baik di negara sendiri maupun di negara lain, sebesar 11,99 ribu US dollar. Peningkatan permintaan akhir pada sektor ini dapat mendorong peningkatan pendapatan masyarakat yang bekerja di sektor lain dalam negeri, sehingga dapat mendorong peningkatan pendapatan nasional.

Ketiga sektor lainnya, yaitu peralatan listrik lain, semikonduktor dan integrated circuits, serta produk elektronik lain juga memiliki angka pengganda pendapatan yang cukup tinggi. Meskipun angka pengganda pendapatan pada tiga sektor ini tidak sebesar pada sektor peralatan elektronik komputasi, tetapi tiga sektor ini juga mampu menciptakan efek pada peningkatan pendapatan yang cukup tinggi 


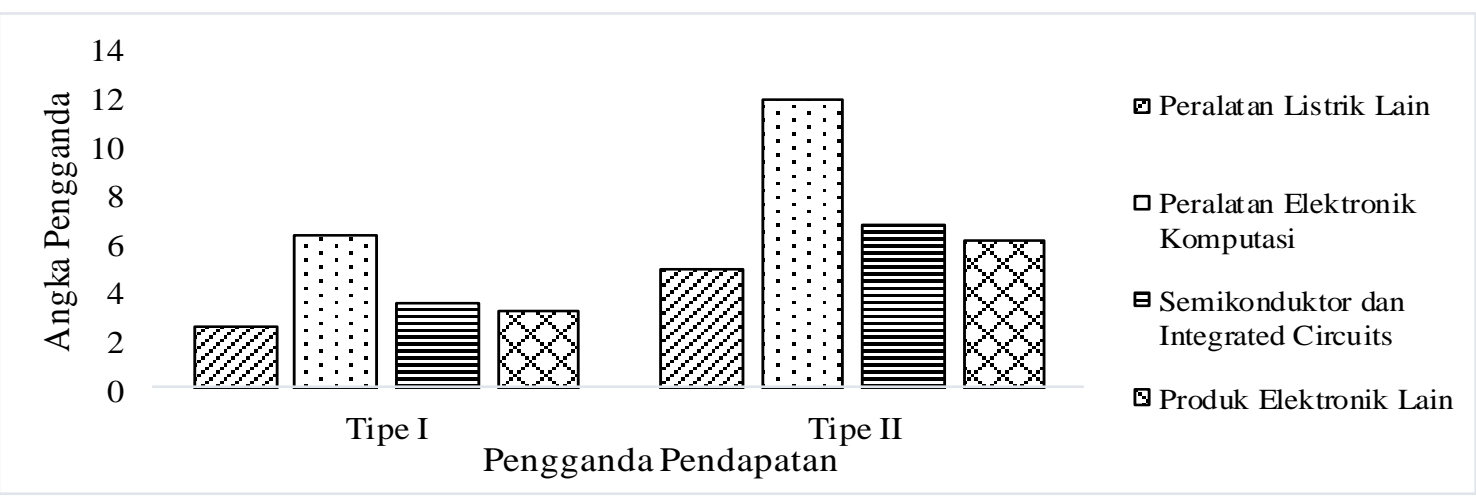

Sumber: IDE-JETRO, 2014a (diolah)

Gambar 7 Pengganda pendapatan tipe I dan tipe II industri elektronik Indonesia tahun 2005

\section{Peningkatan Peran Indonesia dalam Rantai Nilai Global Produk Elektronik}

Berdasarkan hasil penelitian,
terdapat beberapa hal yang dapat
direkomendasikan kepada para
pengambil kebijakan dalam rangka mengembangkan industri elektronik Indonesia sehingga perannya dalam rantai nilai global juga dapat meningkat. Informasi mengenai angka pengganda, baik output maupun pendapatan dapat digunakan untuk menentukan sektor prioritas dalam industri elektronik Indonesia. Angka pengganda output dan pendapatan menunjukkan sektor peralatan elektronik komputasi merupakan sektor yang memiliki angka pengganda paling tinggi dibandingkan tiga sektor lainnya. Oleh karena itu, sektor peralatan elektronik komputasi dapat menjadi prioritas bagi pengembangan industri elektronik Indonesia. Upaya lain yang dapat dilakukan untuk mengembangkan industri elektronik Indonesia, di antaranya:

1. Industri elektronik Indonesia sebagai industri yang memiliki keterkaitan ke belakang yang tinggi perlu didukung dengan menjamin ketersediaan bahan baku, yaitu dengan penyediaan bahan baku dan mengembangkan industri hulu yang menjadi pemasok input bagi industri elektronik.

2. Sektor yang memiliki keterkaitan ke depan yang cukup tinggi, seperti sektor peralatan listrik lain perlu didukung dengan cara mempermudah pemasaran produk.

3. Dalam mendorong kontribusi industri elektronik Indonesia terhadap industri elektronik global diperlukan investasi yang cukup besar, terutama pada sektor yang memiliki dampak pengganda yang tinggi, seperti sektor peralatan elektronik komputasi. Upaya yang dapat dilakukan untuk meningkatkan investasi, di antaranya promosi, pemberian insentif fiskal, mempermudah perizinan berinvestasi, baik dari dalam negeri maupun luar negeri.

\section{KESIMPULAN}

Peran Indonesia dalam rantai nilai global produk elektronik masih sangat rendah. Hal tersebut disebabkan oleh rendahnya kontribusi output industri elektronik Indonesia dalam industri global yang akan berpengaruh pada keuntungan berupa nilai tambah yang diperoleh Indonesia dari rantai nilai global produk elektronik. Indonesia memperoleh nilai tambah yang sangat rendah apabila 
dibandingkan dengan negara-negara lain. Komponen surplus usaha merupakan komponen yang mendominasi nilai tambah bagi industri elektronik Indonesia, yang menunjukkan bahwa industri ini bersifat padat modal.

Industri elektronik Indonesia memiliki peran sebagai pengguna input dari sektor lain. Input yang digunakan mayoritas berasal dari sektor-sektor lain dalam negeri sehingga peningkatan permintaan produk elektronik akan berdampak positif terhadap peningkatan output dan pendapatan nasional. Sektor peralatan elektronik komputasi merupakan sektor prioritas bagi pengembangan industri elektronik Indonesia karena sektor ini berdampak besar dalam meningkatkan perekonomian.

\section{DAFTAR PUSTAKA}

[BPS] Badan Pusat Statistik (ID). 2006. KBLI 2005 - Klasifikasi Baku Lapangan Usaha Indonesia. Jakarta (ID): Badan Pusat Statistik.

[BPS] Badan Pusat Statistik (ID). 2008. Kerangka Teori dan Analisis Tabel Input-Output. Jakarta (ID): Badan Pusat Statistik.

Banga R. 2014. Linking into global value chains is not sufficient: do you export domestic value added contents?. Journal of Economic Integration. 29(2): 267-297.

Cattaneo O, Gereffi G, Miroudot S, Taglioni D. 2013. Joining, upgrading, and being competitive in global value chains, a strategic framework. [Policy Research Working Paper 6406]. Washington DC (US): World Bank.

Chalmers I. 1991. International and regional integration: the political economy of the electronics industry in ASEAN. ASEAN Economic Bulletin. 8(2): 194-209.

Chung NV. 2014. The economic impact of agricultural and clothing, textile: an input-output analysis. Advances in Management \& Applied Economics. 4(1): 27-39.

Daryanto A, Hafizrianda Y. 2010. Analisis Input-Output \& Social Accounting Matrix untuk Pembangunan Ekonomi Daerah. Bogor (ID): PT. Penerbit IPB Press.

[DEKIN] Dewan Kelautan Indonesia (ID). 2012. Analisis Input Output Bidang Kelautan Terhadap Pembangunan Nasional. Jakarta (ID): Dewan Kelautan Indonesia.

[DJKPI] Direktorat Jenderal Kerja Sama Perdagangan Internasional (ID). 2012. Pertemuan pertama Menteri Perdagangan G20: narasi baru, dengan catatan [Internet]. [Diakses 2015 Januari 15]. Tersedia pada http://ditjenkpi. kemendag.go.id/website_kpi/inde x.php?module $=$ news_detail\&news _content_id=1024\&detail $=$ true.

Findlay C. 2015. ASEAN and Regional Free Trade Agreements. New York (US): Routledge.

Gereffi G, Stark KF. 2011. Global Value Chain Analysis: A Primer. North Carolina (US): Center on Globalization, Governance \& Competitiveness (CGGC) Duke University.

Gou D, Webb C, Yamano N. 2009. Towards harmonised bilateral trade data for inter-country inputoutput analyses: statistical issues. [OECD Science, Technology, and Industry Working Papers, 2009/4]. Paris (FR): OECD Publishing. 
Hayashi M. 2005. Structural changes in Indonesian industry and trade: an input-output analysis. The Developing Economies. 43(1): 3971.

[IDE-JETRO] Institute of Developing Economies Japan External Organization. 2014a. Asian International Input-Output Table 2005. Japan (JP): Institute of Developing Economies, Japan External Trade Organization.

[IDE-JETRO] Institute of Developing Economies Japan External Organization. 2014b. Asian International Input-Output Table 2005 - Technical Notes. Japan (JP): Institute of Developing Economies, Japan External Trade Organization. [ILO] International Labour Organization. 2014. Ups and Downs in the Electronic Industry: Fluctuating Production and The Use of Temporary and Other Forms of Employment. Geneva $(\mathrm{CH})$ : International Labour Office Publication.

Ismail. 2015. Prioritas industri substitusi impor [Internet]. [Diakses 2015 Mei 30]. Tersedia pada http://www.republika.co.id/ berita/koran/pareto/15/01/30/nizg dc9-prioritas-industri-substitusiimpor.

Kadarusman Y, Nadvi K. 2013. Competitiveness and technological upgrading in global value chains: evidence from the Indonesian electronics and garment sectors. European Planning Studies. 21(7): 10071028.

[Kadin] Kamar Dagang dan Industri Indonesia (ID). 2010. Kebutuhan Teknologi dan Potensi Kerjasama Riset dengan Industri. Jakarta (ID): Kamar Dagang dan Industri Indonesia.
Kaplinsky R. 1999. Globalisation and unequalization: what can be learned from value chain analysis. Journal of Development Studies. 37(2): 117-146.

Kementerian Perdagangan. 2014. Rantai nilai [Internet]. [Diakses 2015 Januari 15]. Tersedia pada http://inatrims.kemendag.go.id/en/ product/detail/rantai-nilai_ 444/? market $=\mathrm{cn}$.

Koopman R, Powers W, Wang Z, Wei SJ. 2010. Give credit where credit is due: tracing value added in global production chains. [NBER Working Paper Series no. 16426]. Cambridge (GB): National Bureau of Economic Research.

Kuwamori H, Okamoto N. 2007. Industrial Networks between China and the Countries of the Asia-Pacific Region. [IDE Discussion Paper No 110]. Japan (JP): Institute of Developing Economies, Japan External Trade Organization.

Lubis A, Asmara A. 2012. Analisis struktur perilaku dan kinerja perusahaan elektronik setelah pelaksanaan liberalisasi ACFTA. Buletin Ilmiah Litbang Perdagangan. 6(2): 151-168.

Lüthje B. 2002. Electronics contract manufacturing: global production and the international division of labor in the age of the internet. Industry and Innovation. 9(3): 227-247.

Meng B, Fang Y, Yamano N. 2012. Measuring global value chains and regional economic integration: an international inputoutput approach. [IDE Discussion Paper no. 362]. Japan (JP): Institute of Developing Economies, Japan External Trade Organization. 
Nazara S. 2005. Analisis Input Output. Jakarta (ID): Lembaga Penerbit Fakultas Ekonomi Universitas Indonesia.

Powers WM. 2012. The value of value added: measuring global engagement with gross and value-added trade. [Office of Economics Working Paper No. 2012-11A]. Washington DC (US): U.S. International Trade Commision.

Samadikun S. 1985. The development of the electronics industry in Indonesia and the role of the physics department. Di dalam: Parangtopo, Kusno D, editor. Proceedings of the International Conference on Physics and Industry; 1985 September 9-12; Jakarta, Indonesia. Jakarta (ID): University of Indonesia. hlm. 1-4.

Setyawan D. 2011. The development of the electronics industry in Indonesia: policy decisions and revealed comparative advantage [tesis]. Japan (JP): Graduate School, Ritsumeikan Asia Pasific Univesity.

Soejachmoen MP. 2012. Globalization and the electronics industry: is Indonesia missing out. [Forum Kajian Pembangunan]. Jakarta (ID): USAID - SEADI Project.

Sturgeon TJ, Kawakami M. 2010. Global value chains in the electronics industry: was the crisis a window of opportunity for developing countries? [Policy Research Working Paper 5417]. Washington DC (US): World Bank.

Sutrisna MG. 2011. Dampak pengembangan infrastruktur dalam masterplan percepatan dan perluasan pembangunan ekonomi Indonesia terhadap perekonomian Indonesia: Analisa Model Input Output Antar Daerah [tesis]. Jakarta (ID): Program Pascasarjana, Universitas Indonesia.

Van Liemt G. 2007. Subcontracting in electronics: from contract manufacturers to providers of electronic manufacturing services (EMS). [Working Paper 249]. Geneva (CH): International Labour Office.

[WITS] World Integrated Trade Solution. 2015. Product imports by Indonesia from all countries [Internet]. [Diakses 2015 September 7]. Tersedia pada wits.worldbank.org.

Xing Y, Detert N. 2010. How iPhone widens the us trade deficits with prc. [GRIPS Discussion Paper 10-21]. Tokyo (JP): National Graduate Institute for Policy Studies. 